\title{
EKSTRASELÜLER MATRİS YAPISI VE GÖREVLERİ
}

\author{
İbrahim $\ddot{U} C ̧ G \ddot{U} L$ \\ Sultan ARAS \\ Ufuk ELIB $\ddot{U} Y \ddot{U} K^{* * * *}$
}

\begin{abstract}
Öz: Ekstrasellüler matriks (ECM), memeli dokuları içindeki hücrelerin arasında bulunan ve onları destekleyen bir kompleks yapıdır. ECM içinde bulunduğu veya temas halindeki hücreler tarafından salgılanmaktadır. Ekstrasellüler matriks (ECM), geleneksel olarak glikoaminglikanlar ve fibröz proteinler olarak sınıflandırılırlar. Glikoaminglikanlarda kendi içlerinde sülfatlanmamış proteinler (Hyalüronik asit) ve sülfatlanmış proteinler (kondroitin sülfat, keratan sülfat I ve II, heparin, heparan sülfat ve dermatan sülfat) olmak üzere ikiye ayrılır. Fibröz proteinler ise yapısal proteinler (kollajen, elastin) ve yapıştırıcı (adhezyon) proteinler (Fibronektin, laminin, tenaskin, vitronektin, integrin) olarak sinıflandırılır. Yapılan bu çalışma ile hücrelerin yapısı ve hareketini etkileyen, hücre gelişme ve farklılaşmasını etkileyen, su ve mineral tutan, büyüme faktörünü etkileyen ekstrasellüler matris molekülünün yapısı ve bu yapıda bulunan proteinlerin görevlerinden bahsedilmiştir.
\end{abstract}

Anahtar Kelimeler: ECM, Glikoaminglikanlar (GAGs), Fibröz proteinler, Proteoglikanlar

\section{Extracellular Matrix Structure and Tasks}

Abstract: The extracellular matrix (ECM) is a complex structure located between and supporting cells within mammalian tissues. The ECM is secreted by cells in contact or contact. Extracellular matrix (ECM) is traditionally classified as glycosphingolipids and fibrous proteins. In glycosphingolipids, they are divided into two groups: non-sulfated proteins (hyaluronic acid) and sulfated proteins (chondroitin sulfate, keratin sulphate I and II, heparin, heparan sulfate and dermatan sulphate). Fibrous proteins are classified as structural proteins (collagen, elastin) and adhesion proteins (fibronectin, laminin, tenascin, vitronectin, integrin).This work deals with the structure of the extracellular matrix molecule affecting cell growth and differentiation, affecting cell growth and differentiation, water and minerals affecting the growth factor, and the proteins involved in this structure.

Keywords: ECM, Glycosaminoglycans (GAGs), Fibrous proteins, Proteoglycans

\section{GíRIŞ}

İnsan vücudu hiyerarşik biçimde düzenlenmiş kompleks bir yapıdadır. İnsan vücudu sistemlerden, sistemler organlardan, organlar dokulardan, dokular ise hücreler ve hücre dış1 matristen (ECM) oluşmaktadır (Gümüşderelioğlu vd., 2007). Doku mühendisliği; amaca uygun doku ve organ oluşturmak üzere canlı hücrelerin, genellikle polimerlerden oluşan doku iskelesi (scaffold), üzerinde bu hücrelerin ve dokunun biyolojik işleyiş ve organizasyonunun

\footnotetext{
* İbrahim ÜÇGÜL Süleyman Demirel Üniversitesi Mühendislik Fakültesi Tekstil Mühendisliği Bölümü Isparta ** Sultan ARAS Süleyman Demirel Üniversitesi Fen Bilimleri Enstitüsü Biyomühendislik Anabilim Dalı /Isparta **** Ufuk ELIBÜ̈YÜK Süleyman Demirel Üniversitesi Keçiborlu Meslek Yüksekokulu Elektrik ve Enerji Prg. Isparta İletişim Yazarı: Ufuk ELİBÜYÜK (ufukeyk@gmail.com)
} 
oluşturulmasına yönelik bir multidisipliner bilim dalıdır (Uslu ve Arbak, 2010). Doku mühendisliğinde oluşturulan doku iskeleleri ECM'yi taklit edecek biçimde tasarlanmaktadır.

Bir hücre ile çevresi veya diğer hücreler arasındaki etkileşimler, hücre yüzey proteinleri tarafından yönetilir (Wong, 2009). Hücreler biyolojik ortamlarında nanofiber formdaki proteinlerden oluşan bir ekstraselüler matris (ECM) içerisinde bulunmaktadır (Bayram, 2012). Ekstraselüler matris, çok hücreli bir organizmada bazı hücreler tarafından salgılanan, hücreler arasını dolduran ve tanımlanmış bir alanda hücreleri tutan bağlayıcı madde olarak işlev gören çeşitli proteinler ve polisakkaritler için genel bir terimdir (Wong, 2009; Şen, 2012; Yiğit ve di ğ., 2016).

Ekstraselüler matris, başlangıçta asal bir iskelet olarak düşünülmüş ve ana rolü mekanik kuvvet sağlamak iken, günümüzde biyolojik süreçlerin düzenlenmesinde, fiziksel koruma ve sinyallerin sağlanmasında, çoğalma, farklılaşma, oryantasyon gibi hücre davranışlarının yönlendirilmesi ve kolaylaştırılması için aktif bir rol oynayarak, hücrelerin hayatta kalmasını sağlayan üç boyutlu bir yapı olarak kabul edilmektedir (Järveläinen ve diğ., 2009; Onofri, 2016).

Temel olarak, ECM molekülleri; su, polisakkaritler ve proteinlerden oluşur ancak her doku fibroblastlar, epitel ve yağ hücreleri, proteinler gibi farklı hücresel bileşenler arasındaki doku gelişimi sırasında ortaya çıkan dinamik etkileşimlerin sonucu spesifik bir kompozisyona ve topolojiye sahip olurlar (Frantz ve diğ., 2010). Yani ECM molekülleri farklı organlarda farklı miktarlardadır. Beyin ve spinal kanalda çok az bulunurken kemik ve kıkırdakta çok fazla bulunmaktadır. ECM molekülleri her dokuda dokunun fonksiyonel özelliklerine göre farklı özellik taşımaktadırlar; kemik ve dişte kalsifiye (kireçleşmiş) olmuştur. Kornea da şeffaf, tendonlarda ip gibidir ve çok sağlamdır (Ulutin, 2015).

$\mathrm{Bu}$ derlemede, doku iskelesi oluşturmak için bilinmesi gereken önemli ECM bileşenlerinin moleküler kompozisyonu ve yapısal düzeni ayrıca belirgin hücresel aktivitelerin modülasyonundaki rollerine vurgu yapılacaktır.

\section{EKSTRASELÜLER MATRİKSIN YAPISI}

Matriksi oluşturan başlıca iki temel ekstrasellüler protein vardır. Bunlar fibröz ve

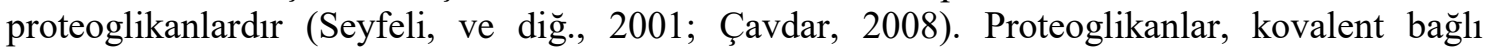
glikozaminoglikanlar içeren peptid zincirleridir. Yapılarında \% 95 karbonhidrat, \% 5 oranında protein içerirler. Hyalüronik asit, kondroitin sülfat, keratan sülfat I ve II, heparin, heparan sülfat ve dermatan sülfat olmak üzere yedi çeşit glikozaminoglikan (GAG) vardır (Çavdar, 2008). Fibröz proteinler yapısal proteinler (kollajen ve elastin) ve yapıştırıcı proteinler (fibronektin, laminin, tenaskin, vitronektin, integrin) olmak üzere iki çeşittir (King, 2017a).

\subsection{Glikoaminoglikanlar (GAGs)}

Bağ dokusunda, proteoglikanlar (PGs), lifli proteinleri gömerek jelatinimsi ve hidratlı bir madde oluştururlar. Proteoglikanlar, bir veya daha fazla polisakkarite bağll, glikozaminoglikanlar (GAGs) olarak adlandırılan merkezi bir proteinden oluşur (Pelosi ve diğ., 2007). Glikozaminoglikanlar uzun, doğrusal ve tekrar eden disakkarid birimlerini içeren heterojen polisakkaritlerdir. $\mathrm{Bu}$ disakkarid birimleri, galaktoz, galaktozamin, $\mathrm{N}$ asetilgalaktozamin-4-sülfat ve galakturonik asittir. İki temel GAG türü vardır. Bunlardan birincisi sülfatlanmamış GAG (hyalüronik asit), ikincisi ise sülfatlanmış GAG'lar (heparan sülfat, heparin, kondroitin sülfat, dermatan sülfat ve keratan sülfat)'dır. Hyalüronik asit haricinde, GAG'lar genellikle proteoglikanlar olarak adlandırılan genel bir yapı oluşturan bir protein çekirdeğine kovalent olarak bağlanırlar. (Scott, 1992; Souza-Fernandes ve diğ., 2006; Pelosi ve diğ., 2007). GAG zincirleri ekstraselüler boşlukların çoğunu doldurur ve dokuya 
mekaniksel desteklik vermekle beraber aynı zamanda suda çözünebilen moleküllerin hızlı difüzyonunu ve hücrelerin göçünü de sağlar (Seyfeli, ve diğ., 2001).

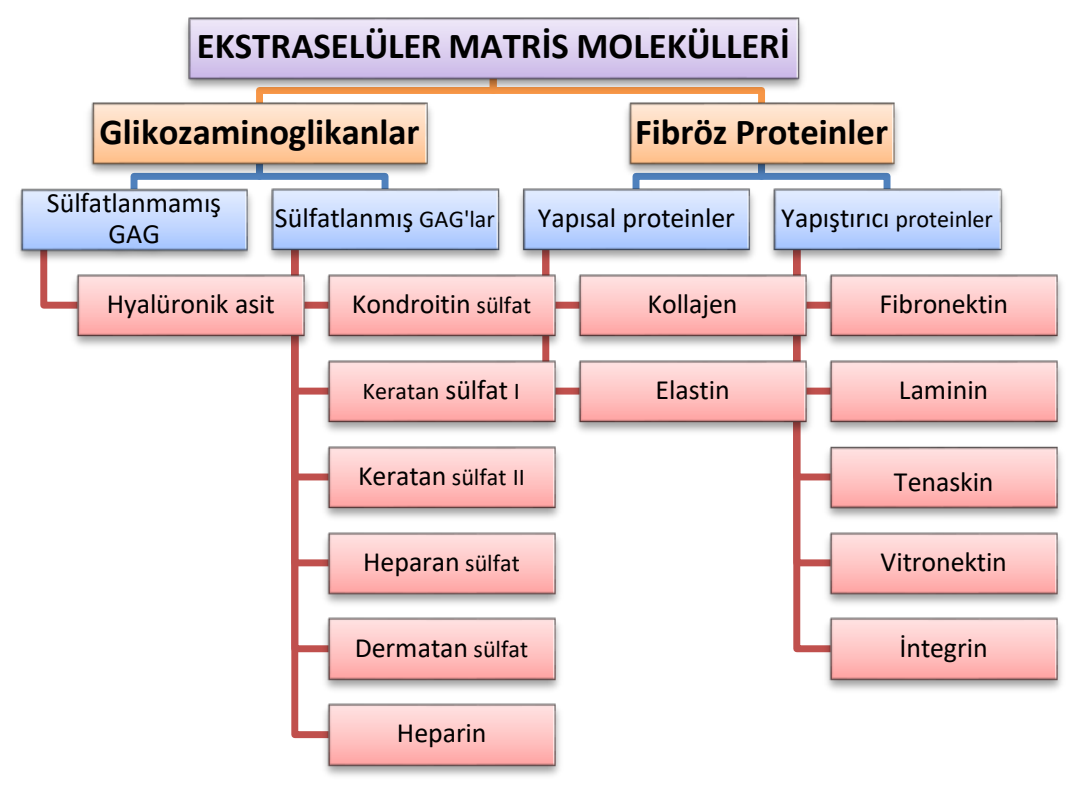

Şekil 1:

Ekstaselüler Matris(ECM) Moleküller

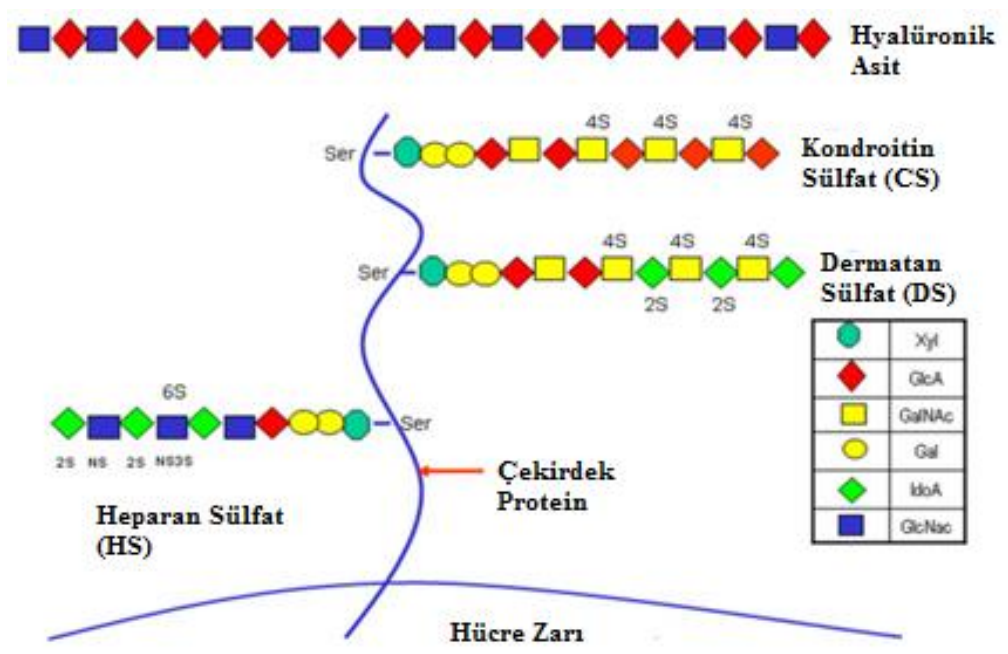

Şekil 2:

Glikozaminoglikan ve Proteoglikanın Şematik Yapısı (Souza-Fernandes ve diğ., 2006)

Şekil 2'de de görüldüğü gibi hyalüronik asidin bir protein çekirdeği ile bağlantısı yoktur. Heparan sülfat, dermatan sülfat ve kondroitin sülfat, bir serin tortusu vasitasıyla proteoglikana bağlanır.

\subsubsection{Sülfatlanmamış glikoaminglikan: hyalüronik asit}

Hyalüronik asit, ECM'deki en bol miktarda bulunan sülfatlanmamış GAG'dır. Hyalüronik asit, diğer GAG'lardan farklıdır, çünkü hücre zarından dışarı atılır, Golgi yoluyla salgılanır ve 
çok büyüktür. Hyalüronik asit, esnek ve sarg1lı bir konfigürasyona sahip, bir Nasetilglukozamine kovalent bağlı bir üronik asit kalıntısı tarafından oluşturulan 10.000'e kadar disakaritten, doğal olarak oluşan doğrusal bir polisakkarittir (Gerdin ve Hällgren, 1997). Öncelikle, bağ dokusu matrisinin ve gevşek bağ dokusunun önemli bir stabilize edici bileşeninin toplanması için gerekli bir molekül olan mezenkimal hücreler tarafından sentezlenir. Hyalüronik asidin değişken fonksiyonlarıyla ilgisi olan benzersiz bir özelliği, yüksek bir anyon yüküdür ve bu da büyük bir çözünme hacmi çekmektedir; Bu hyalüronik asit doku hidrasyonunun önemli bir belirleyicisi haline getirir (Tammi, ve diğ., 2002; Turino ve Cantor, 2003) ve doku onarımı, enfeksiyonlar ve proteolitik granülosit enzimlere karşı korunma sağlamak gibi çeşitli diğer işlevlerde bulunurlar (Li ve diğ., 2000; Cantor ve diğ., 2000).

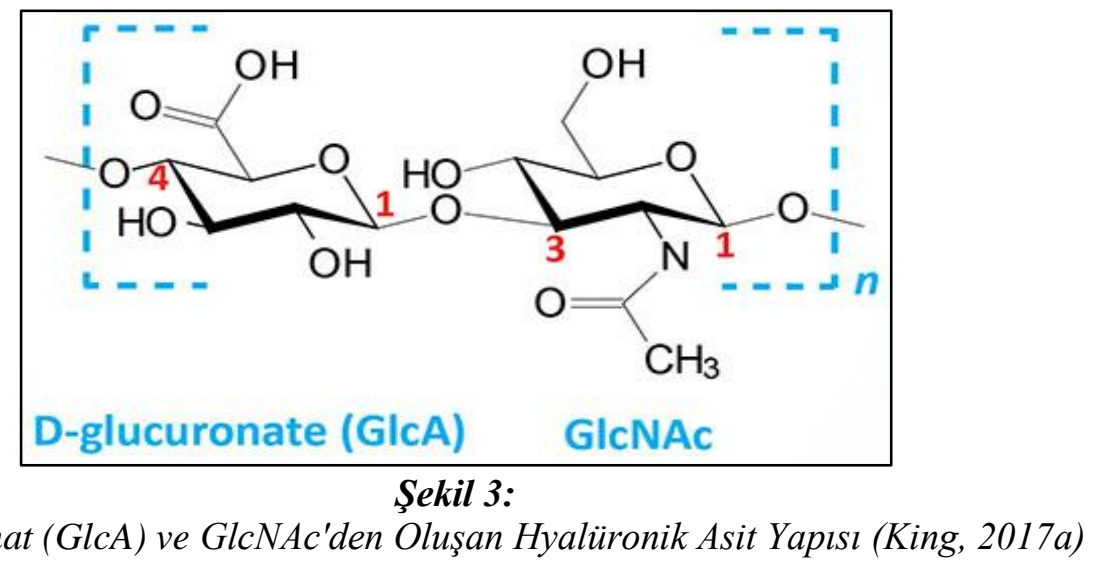

\subsubsection{Sülfatlanmış glikozaminoglikanlar}

Bu tür glikozaminoglikanlar hücre içine salgılanan sülfat ile sentezlenir ve kovalent olarak proteoglikanlara bağlıdırlar. Bu tür GAG'lar, üronik asit (veya galaktoz) ve heksosaminlerden ve yinelenen disakaritlerden oluşan sülfatlı polisakkaritlerdir. GAG'larin polianyonik doğası, proteoglikan moleküllerinin fiziksel özelliklerinin ana belirleyicisidir ve sıkıştırma kuvvetlerine direnç ve aynı anda doku hidrasyonunu sürdürmesine izin verir. Bunlar hiyalüronik aside göre çok daha küçüktür, genellikle sadece 20 ila 200 şeker tortusu uzunluğundadırlar (SouzaFernandes ve diğ., 2006).

Akciğer parankimi içinde en bol sülfatlanmış GAG heparan sülfattır ve vücuda hemen hemen her hücrede eksprese olan ve toplam endotelyal PG'lerin\% 50 ila\% 90'ını oluşturan bir polisakarittir. Başlangıçta hücre yüzeyine bağlı bir biçimde üretilmesine rağmen, aynı zamanda çözünür bir GAG olarak da bırakılabilir. Heparan sülfatın etki mekanizması, proteinin topoğrafik hedefini, yarı ömrünü ve biyoaktivitesini etkileyen çeşitli proteinler ile spesifik ve kovalent olmayan bir etkileşimi içerir. Ayrıca, heparan sülfat, morfogenez, gelişme ve organogenez üzerine etki eder. Heparan sülfat ayrıca hücre-matris etkileşimleri ve kemokinlerin, enzimlerin ve büyüme faktörlerinin aktivasyonu da dâhil olmak üzere çeşitli biyolojik süreçlerde de yer alır (Whitelock ve Iozzo, 2005).

Heparin, heparan sülfatın modifiye edilmiş şeklidir. Bu GAG heparan sülfatın aşırı sülfatlı bir hücre içi varyantı olarak düşünülebilir ve hastalarda yaygın olarak antikoagülan bir ilaç olarak kullanilır (Whitelock ve Iozzo, 2005; Souza-Fernandes ve diğ., 2006). Heparin ve heparan sülfat birçok yapısal ve işlevsel faaliyeti birlikte yapmaktadırlar. Akciğer, zengin bir yerli heparin kaynağıdır. Akciğerde heparininin bolluğu, akciğerin mast hücrelerinden zengin olması ve heparinin üretildiği tek orijinal hücresi olmasından dolayı açıklanabilir. Mast hücresinde heparin, salg1 granüllerinde bulunur; burada, GAG zincirlerinin çoğu, çekirdek proteine (serglikisin) bağlanır ve ticari heparinden çok daha büyük makromoleküler PG'ler oluşturur. $\mathrm{Bu}$, heparinin fizyolojik etkisinin sadece hücrelerde meydana geldiği anlamına 
gelmez, çünkü uyarılmış mast hücreleri hücrenin dışına histamin, kimaz ve triptaz gibi granüle bağlı aracılar ile birlikte heparin salgılarlar (Ruoss ve diğ., 1991).

Kondroitin sülfat, dönüşümlü bağlarla birbirine bağlı alternatif bir D-glukuronat ve Nasetil-D-galaktozamin-4/6-sülfat tortusundan (Şekil 4) oluşur (Šimánek ve diğ., 2005). Eklem kıkırdağında bulunandaki proteoglikanlarda en çok bulunan GAG'dır (Akgün ve Ögüt, 2002). Bağ dokusu hücre dışı matrisinin hiyalin kıkırdak da dahil olmak üzere elastikiyetini ve diğer işlevlerini sağlayan önemli bir bileşenidir. Kondroitin sülfat, nispeten yüksek moleküler ağırlık ve yük yoğunluğu ile heterojen glikosaminoglikanlar ailesine aittir (Tuan, 2004).

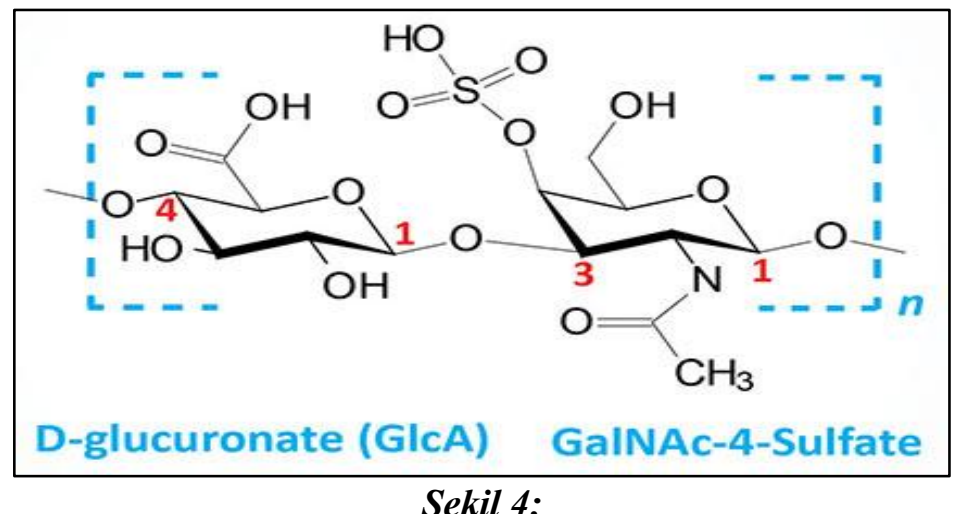

Kondroitin 4- ve 6- Sülfat Yapısı (King, 2017b)

Dermatan sülfat (DS), sülfatlanmış bir glikosaminoglikan olarak sınıflandırılmış olan ve proteoglikanların çekirdek proteinlerine kovalent olarak bağlanan doğrusal bir polisakkarittir (Lozzo, 1998; Mizumoto,2015; Mizumoto, 2017). PG'ler hücre dış1 matrislerde ve hücre yüzeylerinde yaygın olarak bulunur DS-PG'ler ciltde, kıkırdakta ve aortta bol miktarda bulunurlar. Buralar dişında, beyin, karaciğer, akciğer, böbrek ve kalp gibi çeşitli dokularda bulunmaktadırlar. DS zincirleri, 50-200 tekrar içeren L-iduronik asit (IdoUA) ve N-asetil-Dgalaktozamin (GalNAc) kalıntılarını içeren değişen disakarit birimlerini içermektedir (Şekil 5).

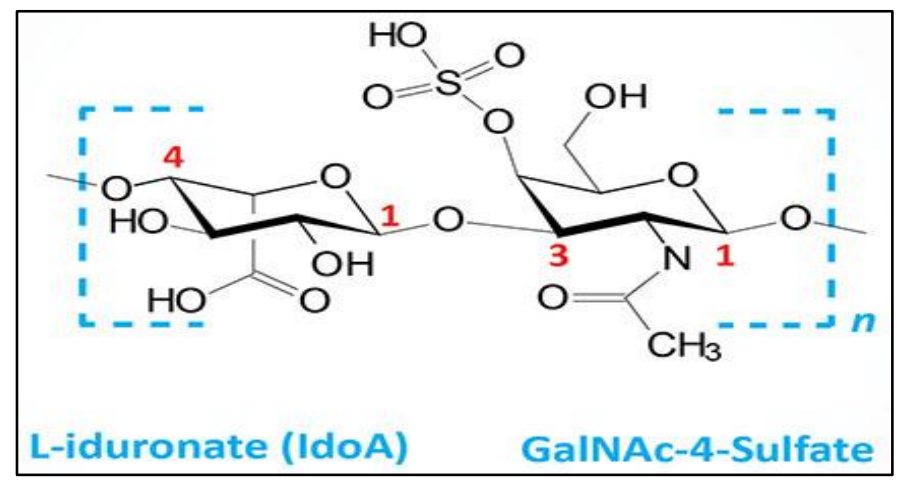

Şekil 5:

Dermatan Sülfat Yapısı (King, 2017b)

DS zincirleri, DS içeren geniş bir biyolojik olay yelpazesinde yapısal bir temel oluşturan IdoUA ve GalNAc artıklarındaki C-2 ve C-4 konumlarındaki sülfatasyon ile modifiye edilirler; hücre dışı matrislerin toplanması, bağlama yoluyla sinyal iletimi, büyüme faktörleri, yara iyileşmesi ve pıhtılaşma görevleri bulunmaktadır (Trowbridge ve Gallo, 2002; Neill ve diğ., 2015; Mizumoto, 2017).

Keratan sülfatlar, oldukça sülfatlanmış bir poli- N- asetil-laktozamin zincirinden [Gal $\beta$ (1 $\rightarrow 4$ ) GlcNAc] oluşur. Keratan terimi başlangıçta GAG yapısının kornea içinde tanımlandığı 
gerçeğine dayanarak üretilmiştir. Ancak benzer bir polisakkarit de kıkırdağın içinde bulunmuştur. İki dokudaki Keratan sülfat, polimer ile proteini birbirine bağlayan oligosakkaritlerde farklılık göstererek keratan sülfat I ve II'yi belirtirler (Funderburgh, 2000; Funderburgh, 2002).

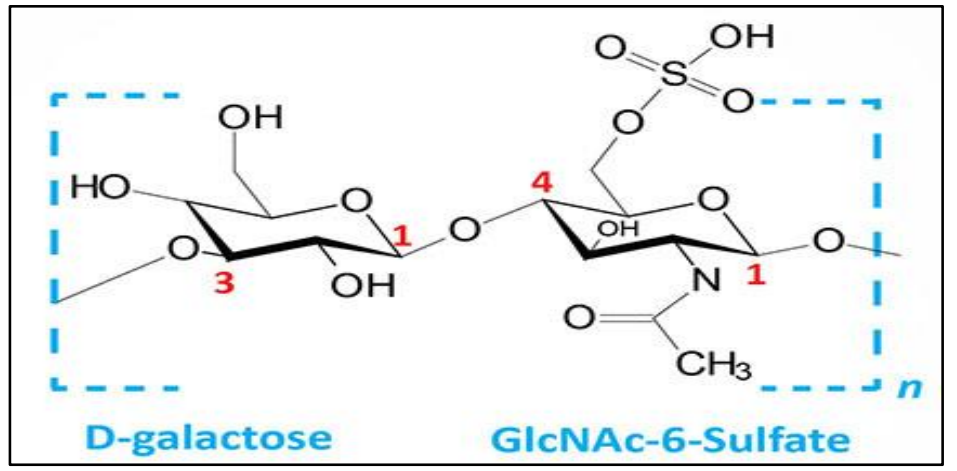

Şekil 6:

Keratan Sülfat Yapısı (King, 2017b)

\subsubsection{Proteoglikanlar}

Akciğerde ana PGs aileleri, GAG kompozisyonu, moleküler ağırlık ve fonksiyona göre ayırt edilebilir: kondroitin sülfat içeren PG (CS-PG: Versikan), heparan sülfat içeren PG'ler (HS-PGs: Perlekan ve Glypikan), Kondroitin ve heparan sülfat içeren PG'ler (CS-HS-PGs: Syndekan) ve dermatansülfat içeren PG'ler (DS-PG: Dekorin) (Pelosi ve diğ., 2007). Bunlar ECM'nin farklı alanlarında bulunurlar (Şekil 7). Bu GAG kompozisyounda heparan sülfat (\% 40-60), bunu takiben kondroitin sülfat / dermatan sülfat (\% 31), hiyalüronan (\% 14) ve heparin (\% 5)'dir (Gill ve diğ., 2010).

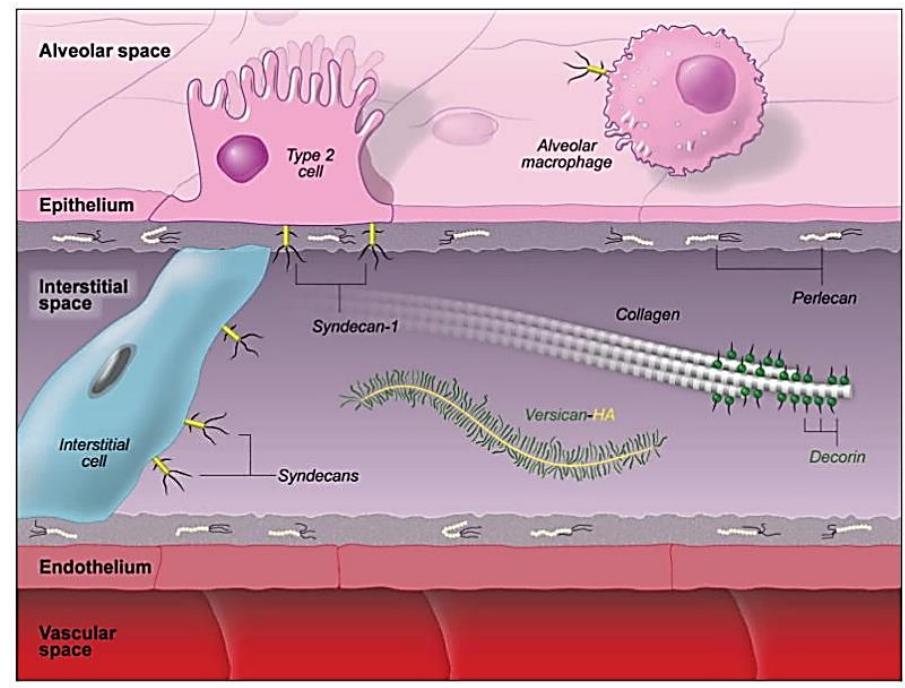

Şekil 7:

Normal akciğerlerde bulunan protoglikanlar (Gill ve diğ., 2010)

Versikan büyük fibroz proteinleri kollajen ve elastin tarafından işgal edilmemiş bölgelerdeki akciğer fibroblastları ve kan damarlarının etrafinda bulunan büyük bir moleküldür $(>1000 \mathrm{kDa})$. Hyalüronik asit ile agregat oluşturur. Versikanın tam işlevi açık değildir ancak doku hidrasyonuna dâhil olduğu düşünülmektedir. Hyaluronik asit, fibronektin ve çeşitli kolajenlerle birlikte hücre-matris etkileşiminde önemli bir rol oynayan agregatları oluşturur. 
Versikan solunum yolları ve akciğer damarları duvarlarında düz kas hücreleri ile bağlantılıdır, hücre-matris yapışmasını, mezenkimal hücrelerin farklılaşmasını düzenler ve yara iyileşmesinde belirli bir rol oynar (Lozzo ve Murdoch, 1996).

Perlekan akciğerdeki en büyük PG'dir ve çekirdeği yaklaşık 4400 amino asit içerir. Perlekan vasküler bazal membranın tipik bir bileşenidir (Yurchenco ve Schittny, 1990) ancak bazı dokuların ECM'lerinde bazal zara yakın olarak da tanımlanmıştır. Gerçekten de, karmaşık çekirdek proteininin çok sayıda protein ile etkileşme potansiyeli vardır. Bazal membranlarda, kolajen IV ile etkileşen ve iki doku bölmesi arasındaki makromoleküllerin veya hücrelerin akışını sınırlayan filtreleme ve bariyer görevi görür. Aynı zamanda, temel fibroblast büyüme faktörü (FGF) ile reseptörü arasındaki etkileşimi düzenler ve doku metabolizmasını modüle eder (Pelosi ve diğ., 2007).

Syndekan ve glypikan hücre yüzeyinde yoğun olarak düzenlenmiştir (Zhao ve diğ., 1999). Sendromun fonksiyonu heparan sülfat zincirleri ve heparin bağlayıcı büyüme faktörleri veya fibronektin ve laminin gibi ekstraselüler proteinlerle olan etkileşimi ile sıklıkla bağlantılıdır ve yara iyileşmesinde rol oynamaktadır (Turnova ve diğ., 2000).

Dekorin, PG içeren en küçük dermatan sülfattır. Dekorin varlığı, fibril oluşum kinetiğini ve ortaya çıkan fibrilin çapını değiştirir (Zhao ve diğ., 1999), doku yenileme modülasyonuna etki eder. Elektron mikroskopu altında incelendiğinde kolajen fibrillerinin yüzey dekorasyonunda bulunduğu görülmüştür.

\subsubsection{Glikozaminoglikanların ana özellikleri}

Yukarıda anlatılmış sülfatlanmamış GAG ve sülfatlanmış GAG’ların yapısı, bulunduğu bölgeler ve görevleri tablo 1'de özetlenmiştir.

Tablo 1. Glikozaminoglikanların ana özellikleri ve karakteristikleri

\begin{tabular}{|c|c|c|c|}
\hline GAG & Yapısı & $\begin{array}{c}\text { Bulunduğu } \\
\text { Yer }\end{array}$ & $\begin{array}{c}\text { İşlevleri } \\
\text { (Referanslar) }\end{array}$ \\
\hline \multirow{8}{*}{ HA } & \multirow{8}{*}{$\begin{array}{l}\text { D-glukuronat }+ \\
\text { GlcNAc }\end{array}$} & \multirow{8}{*}{$\begin{array}{l}\text { Sinoviyal sıvı, } \\
\text { Eklem, } \\
\text { Kıkırdak, } \\
\text { Deri, } \\
\text { Vitreus } \\
\text { humoru, } \\
\text { Gevşek bağ } \\
\text { dokusu } \\
\text { ECM'si }\end{array}$} & $\begin{array}{l}\text { Bağ dokusunun stabilizasyonu } \\
\text { (Gerdin ve Hällgren, 1997) }\end{array}$ \\
\hline & & & $\begin{array}{l}\text { ECM'nin organizasyonu } \\
\text { (Gerdin ve Hällgren, 1997) }\end{array}$ \\
\hline & & & $\begin{array}{l}\text { Nemlendirme ve su homeostazı } \\
\text { (Gerdin ve Hällgren, 1997) }\end{array}$ \\
\hline & & & $\begin{array}{l}\text { Reseptör aracilı sinyalizasyon } \\
\text { (Tammi ve diğ., 2002) }\end{array}$ \\
\hline & & & $\begin{array}{l}\text { Morfogenezis ve doku homeostaz1 } \\
\text { (Sköld ve diğ., 1996; Liv ve diğ., 2000) }\end{array}$ \\
\hline & & & $\begin{array}{l}\text { Enflamatuar cevabın düzenlenmesi } \\
\text { (Cantor ve diğ., 2000) }\end{array}$ \\
\hline & & & $\begin{array}{l}\text { Doku modelleme ve yeniden şekillendirme } \\
\text { (Toole, 1990) }\end{array}$ \\
\hline & & & $\begin{array}{l}\text { Hücresel göç ve fagositoz } \\
\text { (Turino ve Cantor, 2003) }\end{array}$ \\
\hline \multirow{4}{*}{ DS } & \multirow{4}{*}{$\begin{array}{c}\text { L-iduronat }+ \\
\text { GalNAc-4-sülfat }\end{array}$} & \multirow{4}{*}{$\begin{array}{l}\text { Cilt, } \\
\text { Kan } \\
\text { Damarları, } \\
\text { Kalp } \\
\text { Kapakları, } \\
\text { Tendonlar, } \\
\text { Akciğer }\end{array}$} & $\begin{array}{l}\text { Kollajen organizasyonu } \\
\text { (Handel ve diğ., 2005) }\end{array}$ \\
\hline & & & $\begin{array}{l}\text { TGF- } \beta \text { aktivitesinin düzenlenmesi } \\
\text { (Turino ve Cantor, 2003) }\end{array}$ \\
\hline & & & $\begin{array}{l}\text { Bazal membranın stabilizasyonu } \\
\text { (Handel vd., 2005) }\end{array}$ \\
\hline & & & $\begin{array}{l}\text { Hücre ve hücre-matris etkileşimlerinin } \\
\text { düzenlenmesi } \\
\text { (Turino ve Cantor, 2003) }\end{array}$ \\
\hline
\end{tabular}


Tablo 1(devamı) . Glikozaminoglikanların ana özellikleri ve karakteristikleri

\begin{tabular}{|c|c|c|c|}
\hline \multirow{5}{*}{ CS } & \multirow{5}{*}{$\begin{array}{l}\text { D-glukuronat + } \\
\text { GalNAc-4- veya 6- } \\
\text { sülfat }\end{array}$} & \multirow{5}{*}{$\begin{array}{l}\text { Kikırdak, } \\
\text { Kemik, } \\
\text { Kalp valfleri }\end{array}$} & $\begin{array}{l}\text { Enflamasyonun önlenmesi } \\
\text { (Takagaki vd., 2002) }\end{array}$ \\
\hline & & & Bağıșıklık modülasyonu \\
\hline & & & $\begin{array}{l}\text { Kıkırdak yapısının ve fonksiyonunun bakımı } \\
\text { (Takagaki vd., 2002) }\end{array}$ \\
\hline & & & $\begin{array}{l}\text { Kıkırdak şok emici özellikler } \\
\text { (Takagaki vd., 2002) }\end{array}$ \\
\hline & & & $\begin{array}{l}\text { ECM'ye hücre yapışmasının düzenlenmesi } \\
\text { (Takagaki vd., 2002) }\end{array}$ \\
\hline \multirow{3}{*}{ HS } & \multirow{3}{*}{$\begin{array}{l}\text { D-glukuronat-2- } \\
\text { sülfat (veya idonat- } \\
\text { 2-sülfat) + N -sülfo- } \\
\text { D-glukosamin-6- } \\
\text { sülfat }\end{array}$} & \multirow{3}{*}{$\begin{array}{l}\text { Taban zarları, } \\
\text { Hücre yüzeyinin } \\
\text { bileşenleri }\end{array}$} & $\begin{array}{l}\text { Sitokinler, kemokinler ve interlökinler ile } \\
\text { etkileşim (Aviezer vd., 1999; Kreuger vd., } \\
\text { 2002; Handel vd., 2005) }\end{array}$ \\
\hline & & & $\begin{array}{l}\text { Morfogenezis, gelişim ve organogenez } \\
\text { (Whitelock ve Iozzo, 2005) }\end{array}$ \\
\hline & & & $\begin{array}{l}\text { Çeşitli reseptör tirosin kinazları için } \\
\text { korelptörler (Miserocchi vd., 2001) }\end{array}$ \\
\hline \multirow{5}{*}{ Heparin } & \multirow{5}{*}{$\begin{array}{l}\text { D-glukuronat-2- } \\
\text { sülfat (veya idonat- } \\
\text { 2-sülfat) + N -sülfo- } \\
\text { D-glukosamin-6- } \\
\text { sülfat }\end{array}$} & \multirow{5}{*}{$\begin{array}{l}\text { Akciğer, Karaciğer } \\
\text { ve cildin arterlerini } \\
\text { astarlayan mast } \\
\text { hücrelerinin hücre } \\
\text { içi granülleri }\end{array}$} & $\begin{array}{l}\text { Antikoagülan etkiler } \\
\text { (Whitelock ve Iozzo, 2005) }\end{array}$ \\
\hline & & & $\begin{array}{l}\text { Bazı mast hücre triptazlarının stabilizasyonu } \\
\text { (Ruoss vd., 1991) }\end{array}$ \\
\hline & & & $\begin{array}{l}\text { Çeşitli mast hücre kimazlarının aktivitesinin } \\
\text { modülasyonu (Green vd., 1993) }\end{array}$ \\
\hline & & & $\begin{array}{l}\text { Enflamatuar cevabın düzenlenmesi } \\
\text { (Page, 1997) }\end{array}$ \\
\hline & & & $\begin{array}{l}\text { Astımdaki hava yolu duvarının yeniden } \\
\text { modellenmesi (Tyrrell, 1995) }\end{array}$ \\
\hline \multirow{3}{*}{$\mathrm{KS}$} & \multirow{3}{*}{$\begin{array}{c}\text { Galaktoz + } \\
\text { GlcNAc-6-sülfat }\end{array}$} & \multirow{3}{*}{$\begin{array}{l}\text { Kornea, } \\
\text { Kemik, } \\
\text { Kikırdak, }\end{array}$} & $\begin{array}{l}\text { Doku hidrasyonu } \\
\text { (Monzon vd., 2006) }\end{array}$ \\
\hline & & & $\begin{array}{l}\text { Hücre biyolojisi } \\
\text { (Monzon vd., 2006) }\end{array}$ \\
\hline & & & $\begin{array}{l}\text { Hava yolu sekresyonunda en bol GAG } \\
\text { (Matsushita vd., 2005) }\end{array}$ \\
\hline
\end{tabular}

\subsection{Fibröz Proteinler}

Fibröz proteinler 2 çeşittir. Birincisi yapısal proteinler olan kollajen ve elastindir. İkincisi yapıştırıcı proteinler olan fibronektin, laminin, tenaskin ve vitronektin ve integrindir.

\subsubsection{Yapısal proteinler}

Kollajen; fibroblastlar, kondroblastlar, osteoblastlar ve odontoblastlar gibi bağ dokusu hücreleri tarafindan sentezlenen lifli proteinlerden oluşan ve ekzositoz yoluyla ECM'ye salıgılanan bir proteindir (Pereira, 2011). Deri ve kemiğin ana bileşeni olan kollajen, toplam memeli protein kütlesinin yaklaş1k\% 30'unu oluşturan en bol ECM elementidir. Kollajen, çekme mukavemetinden, hücre adezyonunun düzenlenmesinden ve doku gelişiminin yönetiminden sorumludur (Rozario ve DeSimone, 2010).

Kollajenler, uzatılmış bir çubuk şeklinde üçlü sarmal bir yapıya sahip olan bir protein ailesini kapsamaktadır. Bu monomer yapısı her üç konumda glisin $(\% 33,5)$ ve yüksek yoğunluğa sahip amino asitler olan prolin (\%12) ve hidroksiprolin (\%10) son derece karakteristik bir dizilimine bağımlıdır. Kollajen fibrillerini meydana getirmek üzere polimerize olan protein birimi, tropokollajendir. Tropokollajen uzunluğu $280 \mathrm{~nm}$, genişliği $1,5 \mathrm{~nm}$ olan uzamış moleküldür. Tropokollajen üçlü bir sarmal halinde örülmüş üç polipeptid zinciri alt biriminden oluşur. $\mathrm{Bu}$ polipeptid zincirlerinin kimyasal yapısındaki farklılıklar kollajenin 
değişik tiplerinin ortaya çıkmasına sebep olmaktadır (Seyfeli ve diğ., 2001). Günümüzde, 28 farklı tipte kollajen tanımlanmıştır; bu kollajenlerden tip I, ciltte, tendonlarda ve bağ dokuda mevcut olduğu için insan vücudunda en bol miktardadır (Alovskaya ve diğ., 2007; Wilusz ve diğ., 2014).

Bir diğer yapısal bileşen olan elastin, hücre dışı uzayabilir fiberler oluşturan, gerilebilirlik ve dokuların esnekliğinden sorumlu olan yaklaşık 830 aminoasit dizisi içeren bir hidrofobik proteindir (Debelle ve Tamburro 1999). Elastin, kan akımına yardımcı olmak için basınç dalgası yayılımı için bir araç olarak önemli bir işleve sahiptir ve özellikle aort gibi geniş elastik kan damarlarında bol miktarda bulunur (Pereira, 2011). Elastin ayrıca akciğerlerde ve elastik kıkırdakta da çok önemlidir. Elastin, düz kas hücrelerinde ve az miktarda fibroblastlarda sentezlenir. Elastini parçalayan elastazlar, polimorf nüveli lökositlerde ve pankreasta bulunur (Ölmez, 2014).

\subsubsection{Yapıştırıcı proteinler}

Fibronektin, ilk olarak düşük sıcaklıkta çözünemeyen plazma fibrinojeni için bir kirletici olarak 1948'de keşfedildi ve "soğukta çözünmeyen globulin" olarak adlandırıldı. Fibronektin, yüksek molekül ağırlıklı dimerik glikoprotein (dimer başına $450 \mathrm{kDa}$ ) olup (Xu ve Mosher, 2011), endotel, düz kas ve fibroblastlarca üretilen, tüm omurgalıların dokularında yaygın olarak bulunan ve çoğu hücre tipi için potansiyel bir bağlayıcı görevinde olan proteindir. Fibronektin, ECM'de polimerik fibriler ağı ve vücut sıvıları içinde çözünür protomerler olarak mevcuttur. Bu protomerler, C-termini'ndeki bir çift disülfür köprüsü ile antiparalel bir şekilde bağlanmış iki alt birimi kapsamaktadır. Fibronektin mozaik proteininin iyi bir örneğidir, çünkü temel olarak tüm birincil dizisi $\mathrm{V}$ segmenti hariç, üç tip yinelenen aminoasit motifinden oluşur. Fibronektin moleküllerin çok farklı fonksiyonları vardır, bunlardan bazıları; ECM'lerdeki zamansal ve mekansal çökelme, dokuların oluşumu, bakımı ve yeniden şekillenmesi, lenfosit devridaimi, tromboz oluşumu, tümör oluşumu ve metastaz gibi çeşitli normal ve patolojik süreçlerdir. (Johansson ve diğ., 1997).

Laminin, temel zarların önemli glikoprotein bileşeni, iyi bir yapışma molekülü olarak bilinir. Bununla birlikte, bu protean molekülü aynı zamanda hücre fonksiyonunun güçlü bir modülatörüdür. Laminin'e hücre bağlanması, büyük ve giderek daha fazla bilinen fizyolojik olayları başlatır. Bunlar, hücre büyümesinde ve hücre hareketlerinde değişiklikler, epitel farklılaşması, lökosit fagositozunun arttırılması ve nevrit büyümesinin uyarılmasını içerir. Bu işlemlerin tümü için kritik olay, lamininin belirli bir hücre yüzeyi reseptör setine bağlanmasıdır (Mercurio ve Shaw, 1991).

Laminin, disülfid bağlarıyla, bir uzun ve üç kısa kol içeren bir çapraz şekilli moleküle birleştirilen, B1 $(\mathrm{Mr}=222,000), \mathrm{B} 2(\mathrm{MI}=210,000)$ ve A $(\mathrm{M}=400,000)$ olmak üzere üç zincirden (Şekil 8) oluşur (Sasaki ve diğ., 1988). Tek bir gen tarafindan kodlanan ve alternatif bağlanma yoluyla varyantlar üreten fibronektinden farklı olarak, çoklu genler, farklı laminin varyant kombinasyonlarında bir araya gelebilen üç laminin alt biriminin her birini kodlamaktadır (Xu ve Mosher, 2011).

Tenaskin, embriyonik dokularda, özellikle de epitelial mezenkimal kavşaklarda bulunan hücre dış1 matristeki çok fonksiyonlu büyük bir glikoproteindir. Muhtemelen epitelial mezenkimal indüksiyon ve hücre göçünde rol oynamaktadır. Tenascin, bağ dokuları, epitel organlarının mezenkimi ve ayrıca merkezi ve periferik sinir sistemleri gibi birçok gelişmekte olan organda geçici olarak eksprese edilir ve birçok tümörün stromasında tekrar ortaya çıkar (Chiquet-Ehrismann, 1990; Gürbüz ve diğ., 2006).

Vitronektin başlangıçta insan serumunda bir hücre bağlanma faktörü olarak tanımlanan bir glikoproteindir. Aynı zamanda, belirli memeli hücrelerinin hücre dışı matrisinde (ECM) bulunur. Bu çok fonksiyonlu protein hücre adezyonuna aracılık eder, trombini inaktivasyona karşı antitrombin III ile korur ve gözlemci hücrelerini tamamlayıcı olarak sitolizden korur. 
Vitronektin, hem hücre membranına hem de ECM'ye bağlandığ için hücre-ECM yapışmasına aracıl1k eder. Vitronektin, ECM'yi, integrinler olarak bilinen plazma membran reseptörlerinin bir alt kümesi aracılığıyla hücre içi ağa bağlar (Zhu ve diğ., 1994; Peake ve diğ., 1996).

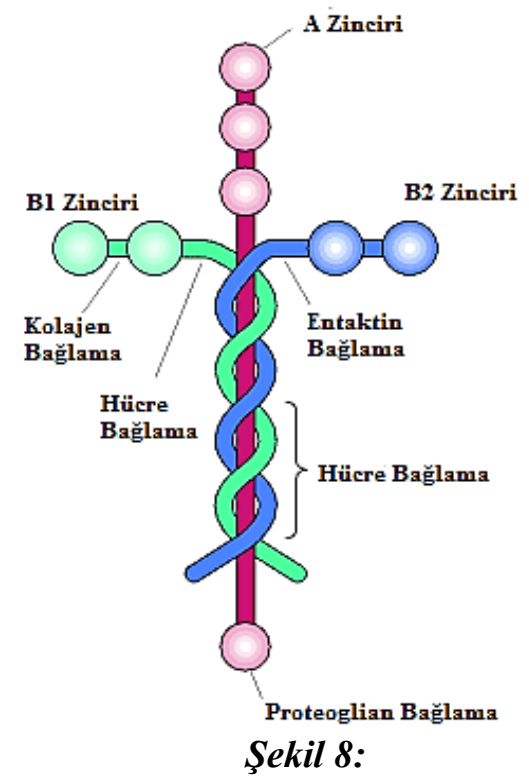

Laminin Şematik Gösterimi (Perdom, 2008)

İntegrinler, hücre dişı matrise (ECM) bağlanmaya aracıllk eden ve hücre göçü ve proliferasyon da dâhil olmak üzere hücre fizyolojisinin kritik regülatörleri olan hemen hemen her hücre tipinde ifade edilen trans membran proteinlerin bir ailesidir. Dinamik membran trafiği (endositoz ve geri dönüşüm), hücrenin göçü sırasında hücre dış1 matrise kuvvet-üreten adezyonların oluşumu ve aktin sitoskeletonunun birleştirilmesi de görev alır. (Ata ve Antonescu, 2017). İntegrinler, kovalent olarak ilişkili $\alpha$ ve $\beta$ alt birimlerinin heterodimerleridir. Omurgalılarda, farklı bağlanma özellikleri ve farklı doku dağılımı ile 24 farklı reseptöre bağlanabilen $18 \alpha$ ve $8 \beta$ altbirimleri bulunmaktadır (Hynes 2002; Barczyk ve diğ., 2010; Campbell ve Humphries, 2011).

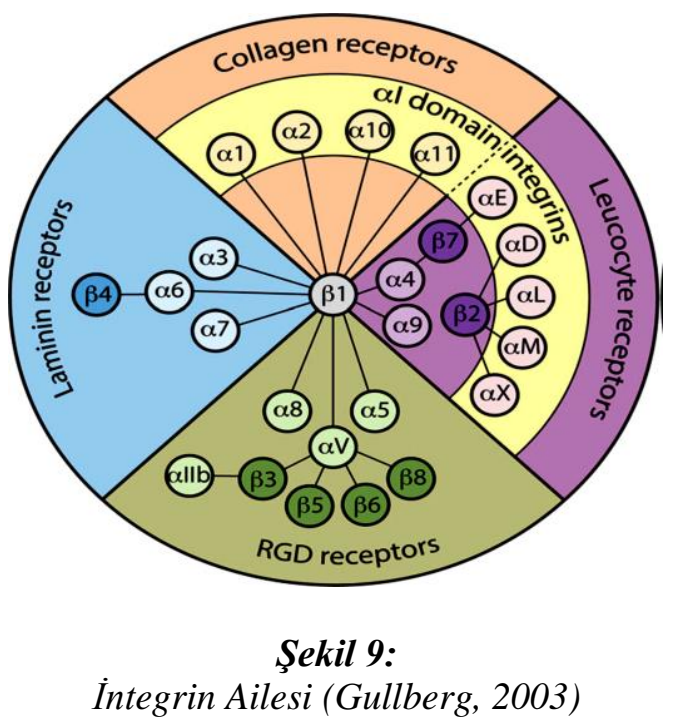


$\alpha$ ve $\beta$ alt birimleri, aralarında esnek bağlayıcılar bulunan birkaç alandan oluşturulmuştur. Her bir alt birim, tek bir membrana uzanan helezona ve genellikle kısa bir yapılandırılmamış sitoplazmik kuyruğa sahiptir. Bu yapısal özellikleri nedeniyle integrinler hücre içi iskeleti ile ECM arasında çok sağlam bir bağ kurabilmektedir. Her alt birimin boyutları farklıdır ancak tipik bir $\alpha$ alt birimi 1000, $\beta$ alt birimi ise 750 aminoasit içerir (Kansu, 1996; Campbell ve Humphries, 2011).

\section{SONUÇ}

Uzun yıllardır, ekstraselüler matrisin (ECM), doku mimarisinin korunması için yalnızca hücreler için yapısal bir destek olarak kullanılması düşünülmüştür. Günümüzde, ECM'nin, zaman ve mekân mimari ipuçlarını tek tek hücrelere sağlayarak, birçok enzimin, peptitlerin, büyüme ve farklılaşma faktörlerin biyo yararlarını modüle eden önemli bir hücre davranışı modülatörü olduğu ortaya çıkmıştır.

ECM, hücreleri çevreleyen ve destekleyen kompleks bir moleküler ağıdır. ECM, gerilme mukavemeti ve elastikiyet sağlayan lifli proteinler, yapışkan glikoproteinler, sıkıştırma kuvvetlerine karşı dirençli bir hidratlanmış jel sağlamak için diğer ECM bileşenleri ile etkileşime giren proteoglikanlardan oluşmuştur. Bu molekül kompleksi aynı zamanda büyüme ve farklılaşma faktörleri, sitokinler ve matris bozucu enzimler (matris metalloproteazlar gibi) ve bunların inhibitörleri gibi birçok molekülü de tutukmaktadır. Bu moleküllerin dağılımı ve organizasyonu, doku işlevine etkisi ve dokudan dokuya yetişkin yaşam boyunca veya embriyonik gelişim sırasında farklılık gösterebilirler. ECM kemik ve kıkırdak dokularının en önemli unsurlarından biridir iken, beyin ve omuriliğin küçük elementidir.

Günümüzde, hücrenin çevrelediği mikro ortamın hücresel aktiviteler tarafından nasıl modüle edildiğini anlamak için büyük bir çaba harcanmaktadır. Ayrıca doku iskelesi üretimi için seçilecek malzemelerin gerek kimyasal gerekse fiziksel yapısı bakımından ECM'nin yapısının ve biyolojik işlevlerinin iyi bilinmesi gerekmektedir. Bu derlemede, önemli ECM bileşenlerinin moleküler kompozisyonu ve yapısal düzeni ayrıca belirgin hücresel aktivitelerin modülasyonundaki rollerine vurgu yapılmıştır.

\section{Teşekkür}

4894-YL1-17 No 'lu Proje ile çalışmamızı maddi olarak destekleyen Süleyman Demirel Üniversitesi Bilimsel Araştırma Projeleri Yönetim Birimi Başkanlığı'na teşekkür ederiz.

\section{KAYNAKLAR}

1. Akgün, I., Öğ̈̈t, T., (2002) Oral Glukozamin ve Kondroitin Sülfatın Osteoartrit Tedavideki Yeri. Türk Ortopedi ve Travmatoloji Birliği Derneği Dergisi, 1(2), 66-70.

2. Alovskaya, A., Alekseeva, T., Phillips, J.B., King, V., Brown, R., (2007) Fibronectin, collagen, fibrin-components of extracellular matrix for nerve regeneration. Topics in Tissue Engineering, 3, 1-26.

3. Ata, R., Antonescu, C.N., (2017) Integrins and Cell Metabolism: an Intimate Relationship Impacting Cancer. International Journal of Molecular Sciences, 18(189), 1-31. doi:10.3390/ijms 18010189

4. Aviezer, D., Safran, M., Yayon, A., (1999) Heparin Differentially Regulates the Interaction of Fibroblast Growth Factor-4 with FGF Receptors 1 And 2. Biochemical and Biophysical Research Communications, 263(3), 621-626. doi: 10.1006/bbrc.1999.1434

5. Barczyk, M., Carracedo, S., Gullberg, D., 2010. Integrins. Cell Tissue Research, 339, 269280. doi: 10.1007/s00441-009-0834-6. 
6. Bayram, C., 2012. Hücre ve Doku Mühendisliği Araştırma Grubu. Nanoteknoloji ve Nanotıp Bilim Dergisi (N@nobülten), 18-27.

7. Bosman, F., ve Stamenkovic, I., (2003) Functional Structure and Composition of the Extracellular Matrix. Journal of Pathology, 200(4), 423-428. doi: 10.1002/path.1437

8. Campbell I.D., Humphries, M.J., (2011) Integrin Structure, Activation, and Interactions. Cold Spring Harbor Perspectives in Biology, 3, 1-14. doi: 10.1101/cshperspect.a004994

9. Cantor, J.O., Shteyngart, B, Cerreta, J.M., Liu, M, Armand, G., Turıno, G.M., (2000) The Effect of Hyaluronan on Elastic Fiber Injury in Vitro and Elastaseinduced Airspace Enlargement in Vivo. Experimental Biology and Medicine, 225(1), 65- 71.

10. Chiquet-Ehrismann, R., (1990) What distinguishes tenascin from fibronectin? FASEB Journal, 4(9), 2598-2604.

11. Çavdar, Z., (2008) Kolon ve Rektum Kanserlerinde Endostatin'in Matriks Metalloproteinaz-2 Üzerine Gösterdiği Etkinin Araştırılması. Dokuz Eylül Üniversitesi, Sağlık Bilimleri Enstitüsü, Biyokimya Anabilim Dalı, Doktora Tezi, 144s., İzmir.

12. De Medeiros Matsushita M., Da Silva, L.F., Dos Santos, M.A., Fernezlian, S., Schrumpf, J.A., Roughley, P., Hiemstra, P.S., Saldiva, P.H., Mauad, T., Dolhnikoff, M., (2005) Airway Proteoglycans are Differentially Altered in Fatal Asthma. The Journal of Pathology, 207(1), 102-110. doi: 10.1002/path.1818

13. Debelle, L., Tamburro, A.M., (1999) Elastin: Molecular Description And Function. The International Journal of Biochemistry \& Cell Biology, 31(2), 261-272. doi.org/10.1016/S1357-2725(98)00098-3

14. Frantz, C., Stewart, K.M., Weaver, V.M., (2010) The Extracellular Matrix at a Glance. Journal of Cell Science, 123(24), 4195-4200. doi: 10.1242/jcs.023820

15. Funderburgh, J.L., (2000) Keratan sulfate: structure, biosynthesis and function. Glycobiology, 10, 951-958. doi.org/10.1093/glycob/10.10.951

16. Funderburgh, J.L., (2002) Keratan Sulfate Biosynthesis. IUBMB Life, 54,187-194. doi: $10.1080 / 15216540214932$

17. Gerdin, B., Hällgren, R., (1997) Dynamic Role of Hyaluronan (HYA) in Connective Tissue Activation and Inflammation. Journal of Internal Medicine, 242(1), 49-55. doi: 10.1046/j.1365-2796.1997.00173.x

18. Gill, S., Wight, T.N., Frevert, C.W., (2010) Proteoglycans: Key Regulators of Pulmonary Inflammation and the Innate Immune Response to Lung Infection. Anat Rec (Hoboken), 293(6), 968-981. doi: 10.1002/ar.21094

19. Green, W.F., Konnaris, K., Woolcock, A.J., 1993. Effect of Salbutamol, Fenoterol, and Sodium Cromoglycate on the Release of Heparin from Sensitized Human Lung Fragments Challenged with Dermatophagoides Pteronyssinus Allergen. American Journal of Respiratory Cell and Molecular Biology, 8(5), 518-521. doi: 10.1165/ajrcmb/8.5.518

20. Gullberg, D., (2003) I domains in integrins. vol 1. Landes Bioscience, Georgetown, Texas. pp 1-185. doi:10.1007/978-94-017-9153-3

21. Gümüşderelioğlu, M., Maviş, B., Karakeçili, A., Kahraman, A.S., Çakmak, S., T1ğlı, S., Demirtaş, T., Aday, S., 2007. Doku Mühendisliğinde Nanoteknoloji. Bilim ve Teknik Dergisi, Yeni Ufuklara Eki, Ekim Sayısı. 
22. Gürbüz, Y., Aydın, Ö., Almaç, A., (2006) Tenascin Expression Patterns Of Salivary Gland Tumors: An Immunhistochemical And Comparative Study. KBB-Forum Dergisi, 5(1), 3540.

23. Handel, T.M., Johnson, Z., Crown, S.E., Lau, E.K., Proudfoot, A.E., (2005) Regulation of Protein Function by Glycosaminoglycans-as Exemplified by Chemokines. Annual Review of Biochemistry, 74, 385-410. doi: 10.1146/annurev.biochem.72.121801.161747

24. Hynes, R.O., (2002) Integrins: Bidirectional, Allosteric Signaling Machines. Cell, 110, 673687. doi.org/10.1016/S0092-8674(02)00971-6

25. Järveläinen, H., Sainio, A., Koulu, M., Wight, T.N., Penttienen, R., (2009) Extracellular Matrix Molecules: Potential Targets in Pharmacotherapy. Pharmacological Reviews, 61(2), 198-223. doi: 10.1124/pr.109.001289

26. Johansson, S., Svineng, G., Wennerberg, K., Armulik, A., Lohikangas, L., (1997) Fibronectin-Integrin Interactions. Frontiers in Bioscience 2, 126-146.

27. Kansu, E., 1996. Hücre Adhezyon Sistemi. Antibiyotik ve Kemoterapi Derneği Dergisi, 10(3), 314-317.

28. King, M.W., (2017) Extacellular Matrix. Erişim Adresi: https://themedicalbiochemistrypage.org/extracellularmatrix.php (Erişim Tarihi: 03.06.2017)

29. King, M.W., (2017) Glycosaminoglycans. Erişim Adresi: https://themedicalbiochemistrypage.org/glycans.php (Erişim Tarihi: 12.06.2017)

30. Kreuger, J., Matsumoto, T., Vanwildemeersch, M., Sasaki, T., Timpl, R., Claesson-Welsh, L., Spillmann, D., Lindahl, U., (2002) Role of Heparan Sulfate Domain Organization in Endostatin Inhibition of Endothelial Cell Function. The EMBO Journal, 21(23), 6303-6311. doi:10.1093/emboj/cdf638

31. Li, Y., Rahmanian, M., Widström, C., Lepperdinger, G., Frost, G.I., Heldin, P., (2000) Irradiation-Induced Expression of Hyaluronan (HA) Synthase 2 and Hyaluronidase 2 Genes in Rat Lung Tissue Accompanies Active Turnover of HA and Induction of Types I and III Collagen Gene Expression. American Journal of Respiratory Cell and Molecular Biology, 23(3), 411-418. doi: 10.1165/ajrcmb.23.3.4102

32. Lozzo, R.V., (1998) Matrix Proteoglycans: From Molecular Design to Cellular Function. Annual Review of Biochemistry, 67, 609-652. doi: 10.1146/annurev.biochem.67.1.609

33. Lozzo, R.V., Murdoch, A.D., (1996) Proteoglycans of the Extracellular Environment: Clues From the Gene and Protein Side Offer Novel Perspectives in Molecular Diversity and Function. The FASEB Journal, 10(5), 598-614.

34. Mercurio, A.M., Shaw, L.M., (1991) Laminin Binding Proteins. BioEssays, 13(9), 469-474. doi: 10.1002/bies.950130907

35. Miserocchi, G., Negrini, D., Passi, A., De Luca, G., (2001) Development of Lung Edema: Interstitial Fluid Dynamics and Molecular Structure. News in Physiological Sciences, 16, 66-71.

36. Mizumoto, S., Yamada, S., Sugahara, K., (2015) Molecular Interactions Between Chondroitin-Dermatan Sulfate And Growth Factors/Receptors/Matrix Proteins. Current Opinion in Structural Biology, 34, 35-42. doi: 10.1016/j.sbi.2015.06.004

37. Mizumoto S., Kosho, T., Yamada, S., Sugahara, K., (2017) Pathophysiological Significance of Dermatan Sulfate Proteoglycans Revealed by Human Genetic Disorders. Pharmaceuticals, 10(34), 1-15. doi: 10.3390/ph10020034 
38. Monzon, M.E., Casalino-Matsuda, S.M., Forteza, R.M., (2006) Identification of Glycosaminoglycans in Human Airway Secretions. American Journal of Respiratory Cell and Molecular Biogoly, 34(2), 135-141. doi: 10.1165/rcmb.2005-0256OC

39. Neill, T., Schaefer, L., Iozzo, R.V., (2015) Decoding The Matrix: Instructive Roles of Proteoglycan Receptors. Biochemistry, 54, 4583-4598. doi: 10.1021/acs.biochem.5b00653

40. Onofri, F., (2016) Development of an Extracellular Matrix Hydrogel For Intestine Tissue Engineering. Università Degli Studi di Padova, Dipartimento di Ingegneria Industriale, Tesi di Laurea Masitrale, 75 p., Padova/Italy.

41. Ölmez, Ü., (2014) Kas-İskelet Sisteminin Yap1 ve Fonksiyonları. Erişim Adresi: http://ichastaliklariromatoloji.medicine.ankara.edu.tr/files/2014/02/Kas-\%C4\%B0skeletSisteminin-Yap\%C4\%B1-ve-Fonksiyonlar\%C4\%B1.pdf (Erişim Tarihi: 20.06.2017)

42. Page, C.P., (1997) Proteoglycans: the "Teflon" of the Airways?. Thorax, 52(10), 924-925. doi.org/10.1136/thx.52.10.924

43. Peake, P.W., Greenstein, J.D., Pussell, B.A., Charlesworth, J.A., (1996) The Behaviour Human Vitronectin in Vivo: Effects of Complement Activation, Conformation and Phosphorylation. Clinical \& Experimental Immunology, 106, 416-422. doi: 10.1046/j.1365-2249.1996.d01-833.x

44. Pelosi, P., Rocco, P.R.M., Negrini, D., Passi, A., (2007) The Extracellular Matrix of the Lung And its Role in Edema Formation. Annals of the Brazilian Academy of Sciences, 79(2), 285-297. doi.org/10.1590/S0001-37652007000200010

45. Pelosi, P., Severgnini, P., Rocco, P.R.M., (2007) The Extracellular Matrix of the Lung. Intersive Care Medicine, Spinger Press, 1040 s., Germany. doi: 10.1007/978-3-540-49433$1 \_29$

46. Perdom, G., (2008) Laminin and the Cross Is There a Connection. Answers in Depth, 3, 8384. Erişim Adresi: https://assets.answersingenesis.org/doc/articles/aid/v3/laminin-cross.pdf (Erişim Tarihi: 05.07.2017)

47. Pereira, I.O., (2011) Design and Construction of a Decellularization Cell. Faculdade de Engenharia, Mestrado Integrado em Bioengenharia, 87 p., Porto.

48. Rozario, T., DeSimone, D.W., (2010) The Extracellular Matrix in Development and Morphogenesis: A Dynamic View. Developmental Biology, 341(1), 126-140. doi: 10.1016/j.ydbio.2009.10.026

49. Ruoss, S.J., Gold, W.M., Caughey, G.H., (1991) Mast Cell Exocytosis: Evidence That Granule Proteoglycan Processing is not Coupled to Degranulation. Biochemical and Biophysical Research Communications, 179(1), 140-146. doi.org/10.1016/0006291X(91)91346-E

50. Sasaki, M., Kleinman, H.K., Hubert, H., Deutzmann, R., Yamada, Y., (1988) Laminin, a Multidomain Protein. The Journal Of Biological Chemistry, 263(32), 16536-16544.

51. Scott, J.E., (1992) Supramolecular Organization of Extracellular Matrix Glycosaminoglycans, in Vitro and in The Tissues. The FASEB Journal, 6(9), 2639-2645.

52. Seyfeli, S., Üstünel, İ., Değer, N., Demir, R., (2001) Ekstrasellüler Matriks ve Baz1 Kardiovasküler Hastalıklarla İlişkisi. Türkiye Klinikleri Kardiyoloji Dergisi, 14(6), 359369. 
53. Šimánek, V., Křen, V., Ulrichová, J., Gallo, J., (2005) The Efficacy of Glucosamine and Chondroitin Sulfate in the Treatment of Osteoarthritis: Are These Saccharides Drugs or Nutraceuticals. Biomedical Papers, 149(1), 51-56.

54. Sköld, C.M., Blaschke, E., Eklund, A., (1996) Transient Increases in Albumin and Hyaluronan in Bronchoalveolar Lavage Fluid After Quitting Smoking: Possible Signs of Reparative Mechanisms. Respiratory Medicine, 90(9), 523-529.

55. Souza-Fernandes A.B., Pelos1, P. Rocco, P.R.M., (2006) The Role of Glycosaminoglycans in Respiratory Disease. Critical Care, 10(6):237, 1-16. doi: 10.1186/cc5069

56. Şen, F., (2012) Matriks Metalloproteinaz-3 (MMP-3) ve Matriks Metalloproteinaz-9 (MMP-9) Gen Polimorfizminin Akut Miyokard İnfarktüsüne Olas1 Etkileri. Mersin Üniversitesi, Tıp Fakültesi, Tıbbi Biyokimya Anabilim Dalı, Uzmanlık Tezi, 104 s., Mersin.

57. Takagaki, K., Munakata, H., Kakizaki, I., Iwafune, M., Itabashi, T., Endo, M., (2002) Domain Structure of Chondroitin Sulfate E Octasaccharides Binding to Type V Collagen. The Journal of Biological Chemistry, 277(11), 8882-8889. doi: 10.1074/jbc.M106479200

58. Tammi, M.I., Day, A.J., Turley, E.A., (2002) Hyaluronan and Homeostasis: A Balancing Act. The Journal of Biological Chemistry, 277, 4581-4584. doi: 10.1074/jbc.R100037200

59. Toole, B.P., (1990) Hyaluronan and its Binding Proteins, the Hyaladherins. Current Opinion in Cell Biology, 2(5), 839-844. doi.org/10.1016/0955-0674(90)90081-O

60. Trowbridge, J.M., Gallo, R.L., (2002) Dermatan Sulfate: New Functions From an Old Glycosaminoglycan. Glycobiology, 12, 117R-125R. doi.org/10.1093/glycob/cwf066

61. Tuan, R.S., (2004) Biology of Developmental and Regenerative Skeletogenesis. Clinical Orthopaedics \& Related Research, 427, 105-117. doi: 10.1097/01.blo.0000143560.41767.ee

62. Turino, G.M., Cantor, J.O.,(2003) Hyaluronan in Respiratory Injury and Repair. American Journal of Respiratory and Critical Care Medicine, 167(9), 1169-1175. doi: 10.1164/rccm.200205-449PP

63. Turnova, S., Woods, A., Couchman, J.R., (2000) Heparan Sulfate Proteoglycans on the Cell Surface: Versatile Coordinators of Cellular Functions. The International Journal of Biochemistry \& Cell Biology, 32(3), 269-288. doi.org/10.1016/S1357-2725(99)00116-8

64. Tyrrell, D.J., (1995) Therapeutic Uses of Heparin Beyond its Traditional Role as an Anticoagulant. Trends in Pharmacological Sciences, 16(6), 198-204. doi.org/10.1016/S0165-6147(00)89022-7

65. Ulutin, T., (2015) Ekstraselüler Matris Ders Notları. Erişim Adresi: http://194.27.141.99/dosya-depo/ders-notlari/turgut-ulutin/Ekstraseluler_Matriks.pdf (Erişim Tarihi: 12.08.2015)

66. Uslu, B., Arbak, S., 2010. Doku Mühendisliğinde Kitosanın Kullanım Alanları. Acıbadem Üniversitesi Sağl1k Bilimleri Dergisi, 1(3), 128-135.

67. Wilusz, R.E., Sanchez-Adams, J., Guilak, F., (2014) The Structure and Function of the Pericellular Matrix of Articular Cartilage. Journal of the International Society for Matrix Biology, 39, 25-32. doi: 10.1016/j.matbio.2014.08.009

68. Wong, E.V., (2009) Cells: Molecules and Mechnisms. Axolotl Academic Publishing Company, 271 p., Louisville, Kentucky/USA.

69. $\mathrm{Xu}$, J., Mosher, D., (2011) Fibronectin and Other Adhesive Glycoproteins. The Extracellular Matrix: an Overview, Biology of Extracellular Matrix, Mecham, R. (Ed), 426, Springer-Verlag Berlin Heidelberg. 
70. Yiğit, A., Yiğit, B., Koşar, Aslan, P., Savaş, H.B., Korkmaz, M., 2016. Doku Mühendisliğinde Deselülerizasyon Metotları ile Ekstraselüler Matriks (ECM) Eldesi ve T1bbi Tedavide Uygulama Alanları. Kimya ve Sanayi Dergisi, 2(6), 29-43.

71. Yurchenco P.D., Schittny, J.C., (1990) Molecular Architecture of Basement Membranes. The FASEB Journal, 4(6), 1577-1590.

72. Zhao, J., Sime, P.J., Bringas, P., Gauldie, J., Warbuton, D., (1999) Adenovirus-Mediated Decorin Gene Transfer Prevents TGF- $\beta$-Induced Inhibition of Lung Morphogenesis. American Journal of Physiology, 277(2), 412-422.

73. Zhu, J.K., Damsz, B., Kononowicz, A.K., Bressan, R.A., Hasegawa, P.M., (1994) A Higher Plant Extracellular Vitronectin-like Adhesion Protein Is Related to the Translational Elongation Factor-I $\alpha$. American Society of Plant Physiologists, 6, 393-404. doi: 10.1105/tpc.6.3.393 